\title{
Video Animasi Pembelajaran Daring pada Mata Pelajaran IPA Kelas VI Sekolah Dasar
}

\section{Komang Sukarini ${ }^{1 *}$, Ida Bagus Surya Manuaba²}

1,2 Program Studi Pendidikan Guru Sekolah Dasar, Universitas Pendidikan Ganesha, Singaraja, Indonesia

\author{
ART I C L E IN F O \\ Article history: \\ Received 2 April 2021 \\ Received in revised form \\ 28 April 2021 \\ Accepted 10 Mei 2021 \\ Available online 25 Juni \\ 2021 \\ Kata Kunci: \\ video, animasi, daring \\ Keywords: \\ video, animation, online \\ learning
}

\begin{abstract}
A B S T R A K
Kurangnya media pembelajaran yang menarik untuk menunjang pembelajaran secara mandiri disituasi pandemi covid-19 menjadi dasar rendahnya minat dan motivasi belajar siswa. Penggunaan media sederhana cenderung menyebabkan siswa cepat merasa bosan. Penelitian ini bertujuan untuk mengembangkan video animasi pembelajaran IPA untuk siswa kelas VI. Jenis penelitian ini yaitu penelitian pengembangan dengan menggunakan model ADDIE. Subjek penelitian meliputi 3 orang ahli dan 9 orang siswa. Metode pengumpulan data yang digunakan berupa angket atau kuesioner, wawancara, pencatatan dokumen. Metode analisis data yang digunakan adalah analisis deskriptif kualitatif dan analisis deskriptif kuantitatif. Hasil review ahli isi pembelajaran memperoleh skor 100\% (berkualifikasi sangat baik), hasil review ahli desain pembelajaran memperoleh skor $100 \%$ (berkualifikasi sangat baik, hasil review ahli media pembelajaran
\end{abstract} memperoleh skor $97 \%$ (berkualifikasi sangat baik), hasil review uji coba perorangan memperoleh skor 94,4\% (berkualifikasi sangat baik), dan hasil review kelompok kecil memperoleh skor 93,4\% (berkualifikasi sangat baik). Dapat disimpulkan bahwa media video animasi yang dikembangkan layak untuk digunakan dalam pembelajaran IPA di kelas VI sekolah dasar. Implikasi penelitian ini yaitu video animasi ini dapat digunakan oleh guru dalam proses pembelajaran sehingga memudahkan siswa dalam memahami materi pembelajaran IPA.

\section{A B S T R A K}

The lack of attractive learning media to support independent learning in the COVID-19 pandemic situation is the basis for the low interest and motivation in student learning. The use of simple media tends to cause students to feel bored quickly. This study aims to develop an animated science learning video for grade VI students. This type of research is development research using the ADDIE model. The research subjects included 3 experts and 9 students. Data collection methods used in the form of questionnaires or questionnaires, interviews, document recording. The data analysis method used is descriptive qualitative analysis and descriptive quantitative analysis. The results of the review of learning content experts obtained a score of $100 \%$ (very well qualified), the results of the review of learning design experts obtained a score of $100 \%$ (very well qualified, the results of the review of learning media experts obtained a score of $97 \%$ (very well qualified), the results of the individual trial review obtained a score of $94.4 \%$ (very good qualification), and the results of a small group review obtained a score of $93.4 \%$ (very good qualification). It can be concluded that the animated video media developed is suitable for use in science learning in grade VI elementary school. This is an animated video that can be used by teachers in the learning process, making it easier for students to understand science learning materials.

\section{Pendahuluan}

Kurikulum 2013 bersifat tematik integratif yang mengambil pokok bahasan pelajaran berdasarkan tema dengan menggabungkan beberapa pelajaran menjadi satu tanpa memberitahu siswa. Pada kurikulum 2013 pembelajaran di sekolah dasar tidak berdiri sendiri lagi melainkan menjadi

Copyright (C) Universitas Pendidikan Ganesha. All rights reserved 
pembelajaran tematik yang memuat semua mata pelajaran termasuk pembelajaran IPA (Astiningtyas, 2018). IPA merupakan salah satu mata pelajaran dasar untuk menanamkan dan mengembangkan pengetahuan, keterampilan, sikap dan nilai ilmiah siswa, serta rasa mencintai dan menghargai kebesaran Tuhan Yang Maha Esa (Khoeriyah \& Mawardi, 2018; Shofiyah, 2018). Tujuan Pembelajaran IPA ditekankan pada kemampuan berpikir kritis yang memberikan pengalaman langsung sehingga siswa dapat mengingat, mengidentifikasi, serta menerapkan pengetahuannya secara ilmiah (Permana \& Nourmavita, 2017; Taiyeb \& Nurul, 2015). Pada hakikatnya, pembelajaran IPA memiliki tujuan merangsang pertumbuhan intelektual dan perkembangan siswa, mendorong terbentuknya sikap berpikir kritis dan rasional agar siswa memiliki konsep-konsep IPA dan keterkaitanya dalam kehidupan sehari-hari (Pambudi et al, 2019). Pembelajaran IPA sangat penting bagi siswa dikarenakan dapat mengembangkan keterampilan dan kemampuan berpikir kritis dalam memahami alam sekitar secara mendalam sehingga mampu mendorong siswa menuju proses penemuan

Pentingnya pembelajaran IPA tentu guru perlu merancang pembelajaran yang menarik bagi siswa. Apalagi dengan kondisi pandemi covid-19 saat ini yang menjadikan pembelajaran dilaksanakan secara daring. Pembelajaran daring merupakan pembelajaran jarak jauh dengan memanfaat teknologi dalam kegiatan pembelajaran dengan menggabungkan beberapa jenis sumber belajar mulai dari buku, gambar, video dan audio (Dewi, 2020; Herliandry, Enjelina, \& Kuswanto, 2020). Dengan kondisi pandemi covid-19 saat ini, guru dituntut untuk mampu menggunakan teknologi dalam mengemas pembelajaran yang menarik sehingga tujuan pembelajaran bisa tercapai meskipun pembelajaran dilaksanakan secara daring (Baber, 2021; U. Rosmiati \& Lestari, 2021). Selain itu guru juga dituntut untuk mampu merancang pembelajaran sesuai dengan kondisi saat ini dan dapat memfasilitasi belajar siswa dengan membuat media pembelajaran yang kreatif, inovatif sehingga dan memudahkan materi untuk dipahami serta menjadikan pembelajaran lebih menyenangkan (Handarini 2020). Kenyataannya saat ini menunjukkan bahwa masih banyak guru yang belum menggunakan media pembelajaran dengan memanfaatkan teknologi dalam mengembangkan media untuk pembelajaran (Hanida, Iriani, \& Arthur, 2015; Kuswanto \& Walusfa, 2017). Hal ini berdampak pada berkurangnya minat dan motivasi belajar siswa sehingga proses belajar menjadi jenuh. Berdasarkan hasil observasi di SD Negeri 2 Kerobokan Kelod ditemukan bahwa penggunaan media dalam pembelajaran belum maksimal, media yang digunakan hanya media sederhana dan media penunjang lainnya berupa buku paket walaupun fasilitas pembelajaran seperti LCD sebenarnya sudah disediakan oleh sekolah. wawancara yang dilakukan pada saat PLPbD (Pengenalan Lapangan Persekolah berbasis Daring) terungkap bahwa hal ini disebabkan oleh kurangnya kemampuan serta keterampilan guru dalam memilih dan mengembangkan media sesuai dengan kebutuhan siswa ditengah kondisi saat ini yang menuntut berjalannya proses pembelajaran melalui strategi daring. Hal ini menyebabkan siswa cenderung bosan pada saat belajar karena kurangnya media pembelajaran yang bervariasi sesuai dengan kebutuhan siswa ditengah masa pandemi covid-19 ini yang diharapkan mampu menarik minat dan memotivasi belajar siswa. Apalagi ditengah masa pandemi covid-19 ini penggunaan media pembelajaran menjadi sangat penting bagi siswa terutama dalam pelaksanaan pembelajaran jarak jauh agar lebih mudah dalam memahami materi pembelajaran.

Dalam mendukung terlaksananya pembelajaran jarak jauh dengan optimal maka diperlukan media pembelajaran. Media inovatif yang perlu dikembangkan yaitu video animasi. Media video animasi merupakan media yang berisi kumpulan gambar-gambar yang berurutan kemudian gambar tersebut digerakan hingga menjadi sebuah video animasi (Kasih, 2017; Trianawati, 2019). Video animasi merupakan sebuah program komputer yang digunakan dalam menyampaikan pembelajaran yang berisikan konten digital dengan kombinasi-kombinasi antara audio, teks, gambar, serta animasi secara keseluruhan yang terpadu (Antika, Priyanto, \& Purnamasari, 2019; Awalia, Pamungkas, \& Alamsyah, 2019). Melalui gabungan dari komponen-komponen seperti teks, gambar, audio, video dan animasi yang terpadu, maka video sangat tepat digunakan untuk memperjelas konsep-konsep yang bersifat abstrak menjadi lebih konkrit (Diyana, Supriana, \& Kusairi, 2020). Dalam video animasi, materi pembelajaran disampaikan melalui visualisasi dinamis sehingga hal ini dapat menghindari terjadinya verbalisasi yang berlebihan dalam proses pembelajaran (Maria, et al., 2019). Penggunaan media animasi dalam pembelajaran berfungsi untuk menarik perhatian siswa dalam belajar sehingga dapat memberikan pemahaman yang lebih cepat (Novita \& Novianty, 2020; M. Rosmiati, 2019). Kelebihan video animasi dalam bidang pendidikan yaitu mampu menyampaikan sesuatu konsep yang kompleks secara visual dan dinamik, menarik perhatian siswa dengan mudah, meningkatkan motivasi serta merangsang pemikiran siswa yang lebih berkesan, animasi juga dapat membantu menyediakan pembelajaran secara maya (Kurniawan et al., 2018). Temuan penelitian sebelumnya juga menyatakan bahwa video animasi terbukti berpengaruh terhadap proses dan hasil belajar siswa (Antika et al., 2019; Awalia et al., 2019). Temuan penelitian lainnya juga menyatakan bahwa video animasi dapat memudahkan siswa dalam belajar sehingga dapat meningkatkan hasil belajar siswa (Rosmiati, 2019; Siddiq, Sudarma, \& Simamora, 2020; 
Wuryanti, 2016). Dapat disimpulkan bahwa media pembelajaran inovatif yang dapat membantu siswa dalam pembelajaran mandiri terlebih ditengah keterbatasan yang dihadapi disituasi pandemi covid-19 dirasa sangat penting untuk dikembangkan. Kelebihan media animasi yang akan dikembangkan yaitu media ini animasi sangat cocok untuk sekolah dasar karena sesuai dengan karakteristik siswa SD yang suka gambar-gambar dan menarik. Tujuan penelitian ini adalah untuk mengembangkan video animasi yang layak digunakan pada mata pelajaran IPA. Diharapkan media ini dapat memfasilitasi belajar siswa sehingga dapat meningkatkan hasil belajar siswa.

\section{Metode}

Penelitian ini merupakan penelitian pengembangan yang dikenal dengan (R\&D) research and development dengan menggunakan model ADDIE. Pemilihan model ini dikarenakan model ADDIE menggunakan pendekatan sistem yang dapat membagi proses perencanaan pembelajaran ke beberapa langkah yang memiliki urutan-urutan logis dan menggunakan output disetiap langkah sebagai input pada langkah berikutnya. Model ADDIE terdiri dari lima tahapan yaitu tahap analisis (analyze), tahap perancangan (design), tahap pengembangan (development), tahap implementasi (implementation), dan tahap evaluasi (evaluation). Penelitian ini dilaksanakan sampai tahap uji coba kelompok kecil dikarenakan masih dalam situasi pandemi covid-19. Subjek penelitian ini adalah dosen yang memiliki latar belakang teknologi pendidikan yaitu dosen ahli isi pembelajaran, dosen ahli desain pembelajaran, dosen ahli media pembelajaran dan siswa kelas VI SD Negeri 2 Kerobokan Kelod.

Subjek uji coba penelitian ini yaitu 1 orang ahli materi pelajaran, 1 orang ahli media pembelajaran, 1 orang ahli desain pembelajaran, 3 orang untuk uji coba perorangan, dan 6 orang siswa untuk uji coba kelompok kecil. Metode pengumpulan data yang digunakan berupa angket atau kuesioner, wawancara, pencatatan dokumen. Instrumen yang digunakan yaitu menggunakan kuesioner atau angket. Data yang terkumpul dalam penelitian ini berupa skor hasil dari pengisian kuesioner, saran, komentar dan masukan terkait produk yang dikembangkan. Teknik analisis yang digunakan dalam penelitian ini yaitu teknik analisis deskriptif kualitatif dan kuantitatif. Teknik analisis ini digunakan untuk mengolah data kualitatif yang diperoleh melalui angket berupa saran, masukan, komentar yang diberikan sedangkan untuk data kuantitatif diperoleh melalui angket dalam bentuk skor yang kemudian dikonversikan menjadi persentase menggunakan konversi tingkat pencapaian skala lima untuk mengetahui tingkat validitas media. Adapun kisi-kisi instrumen kuesioner validitas video animasi pembelajaran dapat disajikan pada Tabel 1,2, 3 dan 4.

Tabel 1. Kisi-kisi Instrumen Uji Validasi Isi Pembelajaran

\begin{tabular}{|c|c|c|}
\hline No & Aspek & Indikator \\
\hline 1 & Pembelajaran & $\begin{array}{l}\text { a. Kesesuaian materi dengan kompetensi dasar } \\
\text { b. Kesesuaian indikator dengan kompetensi dasar } \\
\text { c. Kesesuaian materi dengan tujuan pembelajaran }\end{array}$ \\
\hline 2 & Materi & $\begin{array}{l}\text { a. Keakuratan materi } \\
\text { b. Kejelasan uraian materi } \\
\text { c. Kejelasan contoh-contoh yang diberikan } \\
\text { d. Pentingnya materi } \\
\text { e. Kesesuaian materi dengan situasi siswa } \\
\text { f. Materi mudah dipahami }\end{array}$ \\
\hline 3 & Bahasa & $\begin{array}{l}\text { a. Ketepatan penggunaan istilah sesuai dengan kaidah bahasa } \\
\text { indonesia } \\
\text { b. Kesesuaian bahasa dengan tingkat perkembangan siswa }\end{array}$ \\
\hline 4 & Strategi Pembelajaran & $\begin{array}{l}\text { a. Dukungan media bagi kemandirian dan motivasi belajar siswa } \\
\text { b. Kemampuan media dalam pengetahuan dan pemahaman siswa }\end{array}$ \\
\hline 5 & Evaluasi & $\begin{array}{l}\text { a. Kesesuaian evaluasi dengan materi } \\
\text { b. Kesesuaian tingkat kesulitan soal dengan kompetensi }\end{array}$ \\
\hline
\end{tabular}

(Sumber: diadaptasi dari Suartama 2016)

Tabel 2. Kisi-kisi Instrumen Uji Validasi Desain Pembelajaran

\begin{tabular}{|c|c|c|}
\hline No & Aspek & Indikator \\
\hline 1 & Tampilan Visual & $\begin{array}{l}\text { a. Kemenarikan penampilan media } \\
\text { b. Kejelasan komponen (teks, gambar, audio, animasi) pada media }\end{array}$ \\
\hline 2 & Pembelajaran & a. Kejelasan kompetensi dasar, indikator, tujuan pembelajaran dan \\
\hline
\end{tabular}




\begin{tabular}{|c|c|c|}
\hline No & Aspek & Indikator \\
\hline \multirow{5}{*}{3} & & materi \\
\hline & Materi & a. Ketepatan materi \\
\hline & & b. Kesesuaian urutan materi \\
\hline & & c. Kesesuaian materi dengan tujuan pembelajaran \\
\hline & & d. Kemenarikan uraian materi \\
\hline \multirow[t]{3}{*}{4} & Strategi & a. Dukungan media bagi kemandirian dan motivasi belajar siswa \\
\hline & Pembelajaran & \\
\hline & & $\begin{array}{l}\text { b. Kemampuan media dalam menambah pengetahuan dan pemahaman } \\
\text { siswa }\end{array}$ \\
\hline 5 & Evaluasi & a. Kesesuaian evaluasi dengan indikator pencapaian kompetensi \\
\hline
\end{tabular}

(Sumber: diadaptasi dari Suartama 2016)

Tabel 3. Kisi-kisi Instrumen Uji Validasi Media Pembelajaran

\begin{tabular}{ccl}
\hline No & \multicolumn{1}{c}{ Aspek } & \multicolumn{1}{c}{ Indikator } \\
\hline 1 & Tampilan Visual & a. Kemenarikan tampilan video animasi pembelajaran \\
& b. Tampilan desain aplikasi pembelajaran sesuai dengan karakteristik & siswa \\
& c. Kesesuaian proporsi layout/tata letak \\
& d. Ketepatan pemilihan huruf atau font agar mudah dibaca \\
& e. Kesesuaian penggunaan ukuran huruf atau font \\
& f. Kesesuaian kompesisi warna huruf atau font \\
& g. Kesesuaian penggunaan spasi tulisan agar mudah dibaca \\
& h. Kejelasan teks dalam media \\
& i. Kejelasan penggunaan gambar \\
& j. Kesesuaian penggunaan animasi \\
& k. Kemenarikan animasi \\
& l. Kesesuaian pemilihan audio dengan video pembelajaran \\
& a. Ketepatan penggunaan istilah sesuai dengan kaidah bahasa indonesia \\
& b. Kesesuaian bahasa dengan tingkat perkembangan siswa \\
& c. Kemudahan memahami alur materi melalui penggunaan bahasa \\
& a. Dukungan media bagi kemandirian dan motivasi belajar siswa \\
& b. Kemampuan media dalam menambah pengetahuan dan pemahaman \\
& &
\end{tabular}

(Sumber: diadaptasi dari Suartama 2016)

Tabel 4. Kisi-kisi Instrumen Uji Coba Perorangan dan Kelompok Kecil

\begin{tabular}{cll}
\hline No & \multicolumn{1}{c}{ Aspek } & \\
\hline 1 & Tampilan Visual & a. Kemenarikan tempilan media video animasi pembelajaran \\
2 & Materi & $\begin{array}{l}\text { a. Kejelasan penyampaian materi } \\
\text { b. Kemudahan memahami materi yang disajikan }\end{array}$ \\
& & c. Kesesuaian materi dengan kenyataan dilapangan \\
3 & Bahasa & a. Kejelasan penggunaan bahasa sehingga mudah dipahami \\
4 & Strategi & a. Dukungan media bagi kemandirian belajar siswa
\end{tabular}

(Sumber: diadaptasi dari Suartama 2016)

\section{Hasil dan Pembahasan}

Hasil penelitian ini berupa video animasi pembelajaran pada mata pelajaran IPA kelas VI dengan materi pokok perkembangbiakan hewan. Rancangan media video animasi ini menggunakan model ADDIE yang terdiri dari lima tahapan. Tahap pertama yaitu tahap analisis. Pada tahap ini dilakukan analisis kebutuhan siswa di SD Negeri 2 Kerobokan Kelod dengan melakukan wawancara, pencatatan dokumen 
dengan guru kelas VI di SD Negeri 2 Kerobokan Kelod terkait masalah yang dihadapi dalam pembelajaran. Tahap kedua yaitu tahap desain. Pada tahap ini informasi yang didapatkan pada tahap analisis kebutuhan kemudian digunakan untuk memuat rancangan produk media dalam bentuk flowchart dan story board. Tahap ketiga yaitu tahap pengembangan. Pada tahap ini dilakukan pembuatan produk sesuai dengan flowchart dan story board yang telah dibuat. Pembuatan video animasi ini menggunakan bantuan software photoshop CS6 dalam pembuatan animasi bergerak, powerpoint digunakan dalam pembuatan materi, camtasia digunakan untuk rekam layar (screen recorder), short cut digunakan untuk pengedittan dan penggabungan sehingga menghasilkan produk berupa video animasi. Tahap keempat yaitu tahap implementasi. Pada tahap ini dilakukan review ahli terlebih dahulu sebelum dilakukan uji coba kepada siswa. Review ahli dan uji coba terdiri dari uji ahli isi pembelajaran, uji ahli desain pembelajaran, uji ahli media pembelajaran, uji coba perorangan dan uji coba kelompok kecil, hal ini dilakukan untuk mengetahui kelayakan video animasi yang telah dikembangkan. Tahap kelima yaitu tahap evaluasi. Pada tahap ini dilakukan evaluasi formatif yang digunakan untuk menilai produk yang dikembangkan. Evaluasi formatif mencangkup validitas oleh para ahli dan uji coba produk. Hasil validasi video animasi ditentukan berdasarkan hasil penilaian oleh ahli isi pembelajaran, ahli desain pembelajaran, ahli media pembelajaran, uji coba perorangan, dan uji coba kelompok kecil. Adapun hasil uji validitas dari pengembangan video animasi menurut para ahli dan uji coba produk dapat disajikan pada tabel.

Tabel 6. Hasil Uji Validitas Produk

\begin{tabular}{clcc}
\hline No & Subjek Uji Coba & Hasil Validitas & Keterangan \\
\hline 1 & Uji Ahli Isi Pembelajaran & $100 \%$ & Sangat Baik \\
2 & Uji Ahli Desain Pembelajaran & $100 \%$ & Sangat Baik \\
3 & Uji Ahli Media Pembelajaran & $97 \%$ & Sangat Baik \\
4 & Uji Coba Perorangan & $94,4 \%$ & Sangat Baik \\
5 & Uji Coba Kelompok Kecil & $93,4 \%$ & Sangat Baik \\
\hline
\end{tabular}

Berdasarkan hasil perolehan data tersebut, bahwa video animasi memiliki validitas sangat baik dan layak digunakan hal ini dapat dilihat dari hasil uji validitas menurut ahli isi pembelajaran mendapatkan persentase $100 \%$ (sangat baik), hasil uji validitas ahli desain pembelajaran mendapatkan persentase $100 \%$ (sangat baik), hasil uji validitas ahli media pembelajaran mendapatkan persentase $97 \%$ (sangat baik), hasil uji coba perorangan mendapatkan persentase 94,4\% (sangat baik), hasil uji coba kelompok kecil mendapatkan persentase 93,4\% (sangat baik). Adapun hasil pengembangan produk video animasi ini dapat disajikan sebagai berikut.

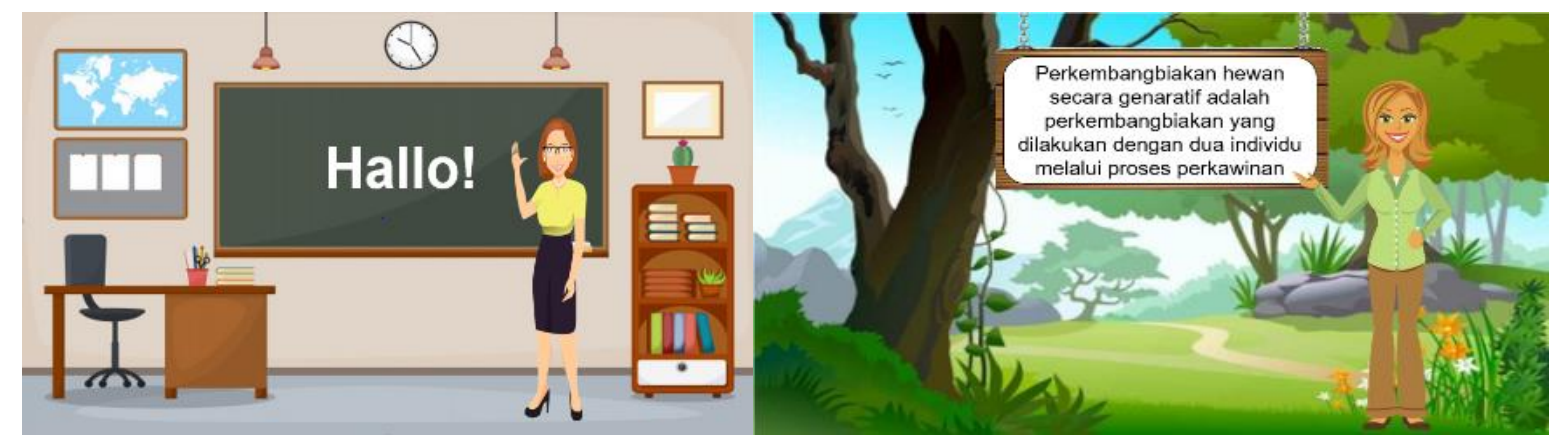

Gambar 2. Video Animasi yang Dikembangkan

Berdasarkan hasil uji validitas yang telah dilakukan, media video animasi pembelajaran yang dikembangkan telah memenuhi kelayakan isi, desain dan media pembelajaran. Dapat disimpulkan bahwa media video animasi pembelajaran yang dikembangkan layak diterapkan dalam proses pembelajaran hal ini disebabkan oleh beberapa faktor yaitu sebagai berikut. Pertama, media video animasi pembelajaran yang dikembangkan layak diterapkan dalam proses pembelajaran karena media ini dapat menarik minat siswa dalam belajar. Pemilihan media yang tepat dengan mengakomodir karakteristik dan kebutuhan peserta didik akan sangat berpeluang dalam mengoptimalkan munculnya potensi yang dimiliki peserta didik. Hal ini juga dapat meningkatkan minat siswa dalam belajar. Adapun karakteristik anak SD pada umumnya adalah sangat menyenangi visual yang menarik dan intraktif, suka bermain, serta senang merasakan ataupun melakukan sesuatu secara langsung (Widiyasanti \& Ayriza, 2018; Yuliani, Antara, \& Magta, 2017). Oleh sebab itu, kemenarikan media pembelajaran akan dapat 
meningkatkan semangat siswa dalam belajar. Penggunaan media pembelajaran yang sesuai dengan karakteristik siswa sebagai alat bantu stimulus pembelajaran yang membantu membangkitkan rasa ingin tahu, motivasi belajar siswa, sehingga pembelajaran dapat tercapai secara maksimal (Afrianti \& Wirman, 2020; Pane \& Darwis Dasopang, 2017). Video animasi yang dikembangkan dapat memotivasi siswa dalam belajar dan dapat mempermudah siswa dalam memahami materi dengan baik. Siswa SD umumnya cenderung cepat jenuh pada saat mengikuti pembelajaran mengakibatkan kurangnya motivasi saat belajar sehingga dengan adanya media video animasi yang sesuai karakteristik siswa, maka video ini mampu meningkatkan semangat siswa pada saat mengikuti pembelajaran. Dalam merancang media pembelajaran yang efektif harus memenuhi beberapa syarat seperti media dibuat sederhana mungkin, mudah dipahami, menarik sehingga siswa termotivasi untuk belajar (Supriyono, 2018). Video animasi di desain secara menarik dengan tampilan gambar-gambar bergerak dan warna yang menarik di dalam video animasi sehingga sesuai dengan karakter siswa SD. Siswa SD yang cenderung lebih tertarik kepada hal-hal yang bergerak yang mengakibatkan siswa ingin mengetahui sebab-sebab terjadinya sesuatu. Hal ini menjadi salah satu dasar pertimbangan dari dipilihnya media video dengan animasi sebagai unsur utamanya. Muslina, et al (2018) menjelaskan bahwa warna-warna dan gambar dapat menarik perhatian serta menambah motivasi belajar siswa. Video animasi dapat menyampaikan suatu konsep yang rumit, dan menarik perhatian, meningkatkan motivasi, dan merangsang pemikiran siswa, dapat menyajikan pesan yang lebih baik dibanding dengan media lain, serta dapat digunakan untuk menyediakan pembelajaran secara maya (Jatmik, (2017)

Kedua, video animasi pembelajaran yang dikembangkan layak diterapkan dalam proses pembelajaran karena dapat memudahkan siswa memahami materi pembelajaran. Dari segi konten, materi yang ada pada video animasi ini sesuai dengan kompetensi dasar, indikator, tujuan pembelajaran. Selain itu kesesuaian media video animasi dengan karakteristik siswa SD dan materi yang disampaikan mudah dipahami. Kesesuaian media dengan materi serta karakteristik siswa akan memudahkan siswa dalam mencerna informasi yang disajikan (Afandi, 2015; Divayana, Hendra, Suyasa, \& Sugihartini, 2016; Fitrianti, Handayani, \& Suyitno, 2020). Kesesuaian materi media dengan KD, Indikator maupun tujuan adalah suatu hal yang sangat penting dari pengembangan video animasi ini. Kompetensi dasar adalah kemampuan yang harus dikuasai peserta didik setelah mereka melaksanakan pembelajaran. Dalam implementasi proses pembelajaran, Kompetensi dasar menjadi acuan penting dari seberapa jauh dan seberapa dalam materi yang harus disampaikan oleh seorang guru kepada siswa mengingat keterbatasan kemampuan otak dalam memproses informasi (Diani \& Niken, 2018; Irwandi, 2020). Termasuk dalam pengembangan video animasi pada mata pelajaran IPA kelas VI SD pun materi yang disampaikan wajib mengikuti kompetensi dasar dengan indikator sebagi pedoman sekaligus pengukur kedalaman dan keluasan materi yang dsampaikan sehingga siswa dapat menguasai materi/ pengetahuan sesuai dengan yang distandarkan dalam KD. Tujuan pembelajaran dalam hal ini menggambarkan proses dan hasil belajar yang diharapkan dicapai secara terukur oleh peserta didik sesuai dengan kompetensi dasar yang menjadi acuan penilaian mata pelajaran. Kesesuaian kompetensi dasar, indikator, tujuan yang jelas, dapat menjadi acuan dalam setiap proses pembelajaran yang dilangsungkan sehingga kegiatan pembelajaran berdampak positif pada hasil dan tujuan pembelajaran dapat tercapai (Twiningsih \& Sayekti, 2020; Wijoyo, 2018).

Langkah-langkah dalam penyampaian materi dalam video yaitu logis dan terstruktur. Pada media video animasi pembelajaran IPA ini, materi yang merupakan stimulus belajar disajikan dengan sederhana dan sistematis melalui berbagai ilustasi dan contoh-contoh mudah dipahami oleh siswa. Ilustrasi yang menarik juga dapat memudahkan siswa dalam memahami materi pembelajaran (Anwariningsih \& Ernawati, 2013; Nababan, 2020). Siswa membutuhkan berbagai strategi belajar menarik untuk mencapai hasil yang optimal. Dengan pemaparan materi dengan ilustrasi dan contoh yang dikemas dengan menarik melalui perpaduan gambar, teks, animasi dan unur interaksi dengan siswa menjadikan siswa terlibat aktif dan semakin termotivasi dalam proses pembelajaran. Silmi dan Rachmadyanti (2018) menyatakan bahwa dalam penggunaan media pembelajaran tidak hanya di titik beratkan pada tujuan dan isi dari media pembelajaran tetapi perlu juga dipertimbangkan faktor-faktor lain yang berperan dalam penggunaan media seperti karakteristik siswa, model atau strategi pembelajaran, alokasi waktu, sarana dan prasarana, dan sebagainya.

Temuan penelitian sebelumnya menyatakan bahwa video animasi dapat meningkatkan minat serta motivasi dalam belajar karena penyajiannya yang menarik (Dwipayana, 2013; Imamah, 2012). Temuan penelitian lainnya juga menyatakan bahwa video animasi dapat meningkatkan hasil belajar siswa (Taqiya, Nuroso, \& Reffiane, 2019; Wuryanti, 2016). Kelebihan media video animasi ini yaitu materi disajikan dengan sederhana dan sistematis melalui berbagai ilustasi dan contoh-contoh mudah dipahami oleh siswa siswa. Ilustrasi yang menarik dapat memudahkan siswa dalam memahami materi pembelajaran. Kelemahan penelitian ini yaitu media ini belum sampai tahap efektivitas, namun tetap 
layak digunakan karena telah melewati uji validitas produk. Implikasi penelitian ini yaitu media yang dikembangkan dapat digunakan oleh guru dalam mengajar sehingga memudahkan siswa dalam memahami materi pelajaran. Hal ini akan berdampak pada hasil belajar siswa yang meningkat.

\section{Simpulan}

Video animasi yang dikembangkan mendapatkan kategori sangat baik. Dapat disimpulkan bahwa video animasi yang dikembangkan layak digunakan dalam pembelajaran IPA sekolah dasar. Direkomendasikan kepada guru untuk menggunakan video animasi dalam proses pembelajaran agar memudahkan siswa dalam belajar khususnya pada pelajaran IPA sehingga berdampak pada hasil belajar siswa yang meningkat.

\section{Daftar Rujukan}

Afandi, R. (2015). Pengembangan Media Pembelajaran Permainan Ular Tangga Untuk Meningkatkan Motivasi Belajar Siswa dan Hasil Belajar IPS di Sekolah Dasar. INoP (Jurnal Inovasi Pembelajaran), 1(1). https://doi.org/https://doi.org/10.22219/jinop.v1i1.2450.

Afrianti, Y., \& Wirman, A. (2020). Penggunaan Media Busy Book Untuk Menstimulasi Kemampuan $\begin{array}{lllll}\text { Membaca Anak. Jurnal Pendidikan } & \text { Tambusai, }\end{array}$ https://doi.org/https://doi.org/10.31004/jptam.v4i2.578.

Antika, H., Priyanto, W., \& Purnamasari, I. (2019). Pengaruh Penggunaan Media Animasi Sandisko Dengan Model Somatic Auditory Visualization Intellectually Terhadap Hasil Belajar Tema Kebersamaan Kelas 2. Mimbar Ilmu, 24(2). https://doi.org/http://dx.doi.org/10.23887/mi.v24i2.21288.

Anwariningsih, \& Ernawati. (2013). Development of Interactive Media for ICT Learning at Elementary School based on Student Self Learning. Journal of Education and Learning, 7(2), 121-128. https://doi.org/http://dx.doi.org/10.11591/edulearn.v7i2.226.

Astiningtyas, A. (2018). Kesiapan Guru Sekolah Dasar Dalam Pelaksanaan Pembelajaran Tematik Integratif Pada Kurikulum 2013. Primary: Jurnal Pendidikan Guru Sekolah Dasar, 7(1), 60. https://doi.org/10.33578/jpfkip.v7i1.5340.

Awalia, I., Pamungkas, \& Alamsyah. (2019). Pengembangan Media Pembelajaran Animasi Powtoon pada Mata Pelajaran Matematika di Kelas IV. Jurnal Matematika Kreatif-Inovatif, 10(1). https://doi.org/https://doi.org/10.15294/kreano.v10i1.18534.

Baber, H. (2021). Modelling the acceptance of e-learning during the pandemic of COVID-19-A study of South Korea. The International Journal of Management Education, 19(2). https://doi.org/https://doi.org/10.1016/j.ijme.2021.100503.

Dewi, W. A. F. (2020). Dampak COVID-19 terhadap Implementasi Pembelajaran Daring di Sekolah Dasar. Edukatif: Jurnal Ilmu Pendidikan, 2(1), 55-61. https://doi.org/10.31004/edukatif.v2i1.89.

Diani, R., \& Niken, S. H. (2018). Flipbook Berbasis Literasi Islam: Pengembangan Media Pembelajaran Fisika dengan 3d Pageflip Professional Flipbook Based On Islamic Literacy: The Development Of Physics Learning Media Using 3d Pageflip Professional." 4(2):234-44. Jurnal Inovasi Pendidikan IPA, 4(2). https://doi.org/https://doi.org/10.21831/jipi.v4i2.20819.

Divayana, Hendra, D. G., Suyasa, W. A., \& Sugihartini, N. (2016). Pengembangan Media Pembelajaran Berbasis Web Untuk Matakuliah Kurikulum dan Pengajaran di Jurusan Pendidikan Teknik Informatika Universitas Pendidikan Ganesha. Jurnal Nasional Pendidikan Teknik Informatika (JANAPATI), 5(3), 149-157. https://doi.org/http://dx.doi.org/10.23887/janapati.v5i3.9922.

Diyana, T. N., Supriana, E., \& Kusairi, S. (2020). Pengembangan multimedia interaktif topik prinsip Archimedes untuk mengoptimalkan student centered learning. Jurnal Inovasi Teknologi Pendidikan, 6(2), 171-182. https://doi.org/10.21831/jitp.v6i2.27672.

Dwipayana, I. K. (2013). Kemampuan Siswa Dalam Pelajaran Biologi Dengan Menggunakan Media Pembelajaran Berbasis Video Animasi Pada Siswa Kelas VII DI SMP Negeri 2 Singaraja Tahun Pelajaran 2011/2012. Jurnal Edutech Undiksha, 1(1). https://doi.org/http://dx.doi.org/10.23887/jeu.v1i1.360.

Feny Rita Fiantika, dan, Matematika, P., \& Nusantara PGRI Kediri, U. (2017). Sebuah Rekam Jejak Proses Pembuatan Perangkat Pembelajaran Berbasis Video Animasi 3D Portofolio. Jurnal Math Educator Nusantara, 8(76), 1-4.

Fitrianti, I., Handayani, \& Suyitno. (2020). Keefektifan Media Magic Box Terhadap Hasil Belajar Matematika Materi Jaring-Jaring Bangun Ruang Sederhana. MIMBAR PGSD Undiksha, 8(2), 323329. https://doi.org/http://dx.doi.org/10.23887/jjpgsd.v8i2.26677.

Handarini, O. I. (2020). Daring to draw causal claims from non-randomized studies of primary care interventions. Jurnal Pendidikan Administrasi Perkantoran, 8(3), 496-503. 
https://doi.org/10.1093/fampra/cmy005.

Hanida, E. Y., Iriani, T., \& Arthur, R. (2015). Pengembangan Media Pembelajaran Multimedia Interaktif CAI Pada Mata Pelajaran Mekanika Teknik Kelas X di SMK Negeri 1 Jakarta. Jurnal Pensil: Pendidikan Teknik Sipil, 4(2). https://doi.org/https://doi.org/10.21009/jpensil.v4i2.9879.

Herliandry, Enjelina, \& Kuswanto. (2020). Pembelajaran Pada Masa Pandemi Covid-19. Jurnal Teknologi Pendidikan, 22(1). Retrieved from https://doi.org/10.21009/jtp.v22i1.15286.

Imamah, N. (2012). Peningkatan Hasil Belajar IPA Melalui Pembelajaran Kooperatif Berbasis Konstruktivisme Dipadukan Dengan Video Animasi Materi Sistem Kehidupan Tumbuhan. Jurnal Pendidikan IPA Indonesia, 1(1). https://doi.org/https://doi.org.10.15294/jpii.v1i1.2010.

Irwandi. (2020). Penggunaan Media Audio Visual Dalam Peningkatan Hasil Belajar Materi Rukun Iman Pada Siswa Kelas I SD Negeri 49 Kota Banda Aceh. Pionir Jurnal Pendidikan, 9(1), 25-44. https://doi.org/http://dx.doi.org/10.22373/pjp.v7i1.3321.

Kasih, F. (2017). Pengembangan Film Animasi dalam Pembelajaran Fisika pada Materi Kesetimbangan Benda Tegar di SMA. Jurnal Keguruan Dan Ilmu Tarbiyah, 2(1), 41-47. https://doi.org/https://doi.org/10.24042/tadris.v2i1.1737.

Khoeriyah, N., \& Mawardi, M. (2018). Penerapan Desain Pembelajaran Tematik Integratif Alternatif Berbasis Kearifan Lokal untuk Meningkatkan Hasil dan Kebermaknaan Belajar. Mimbar Sekolah Dasar, 5(2), 63. https://doi.org/10.17509/mimbar-sd.v5i2.11444.

Kurniawan, D., Kuswandi, D., \& Husna, A. (2018). Pengembangan Media Video Pembelajaran Pada Mata Pelajaran Ipa Tentang Sifat Dan Perubahan Wujud Benda Kelas Iv Sdn Merjosari 5 Malang. JINOTEP (Jurnal Inovasi Dan Teknologi Pembelajaran) Kajian Dan Riset Dalam Teknologi Pembelajaran, 4(2), 119-125. https://doi.org/10.17977/um031v4i22018p119.

Kuswanto, J., \& Walusfa, Y. (2017). Pengembangan Multimedia Pembelajaran pada Mata Pelajaran Teknologi Informasi dan Komunikasi Kelas VIII. Innovative Journal of Curriculum and Educational Technology IJCET, 6(2), 58-64. https://doi.org/https://doi.org/10.15294/ijcet.v6i2.19335.

Maria, U., Rusilowati, A., \& Hardyanto, W. (2019). Interactive Multimedia Development in The Learning Process of Indonesian Culture Introduction Theme for 5-6 Year Old Children. Journal of Primary Education, 8(3), 344-353.

Muslina, M., Halim, A., \& Khaldun, I. (2018). Kelayakan Media Animasi Hukum Newton Ii Tentang Gerak Pada Bidang Miring Dan Katrol Di Sma Kabupaten Aceh Besar. Jurnal IPA \& Pembelajaran IPA, 1(1), 64-72. https://doi.org/10.24815/jipi.v1i1.9568.

Nababan, N. (2020). Pengembangan Media Pembelajaran Berbasis Geogebra Dengan Model Pengembangan Addie Di Kelas Xi Sman 3 Medan ( Development of Geogebra-Based Learning Media With Addie Development Models in Class Xi Sman 3 Medan ). Inspiratif: Jurnal Pendidikan Matematika, 6(1), 37-50. https://doi.org/https://doi.org/10.24114/jpmi.v6i1.19657.

Novita, L., \& Novianty, A. (2020). Pengaruh Penggunaan Media Pembelajaran Audio Visual Animasi Terhadap Hasil Belajar Subtema Benda Tunggal Dan Campuran. JTIEE (Journal of Teaching in Elementary Education), 3(1), 46. https://doi.org/10.30587/jtiee.v3i1.1127.

Pambudi, B., Efendi, R. B., Novianti, L. A., Novitasari, D., \& Ngazizah, N. (2019). Pengembangan Alat Peraga IPA dari Barang Bekas untuk Meningkatkan Motivasi Belajar dan Pemahaman Siswa Sekolah Dasar. Indonesian Journal of Primary Education, 2(2), 28. https://doi.org/10.17509/ijpe.v2i2.15097.

Pane, A., \& Darwis Dasopang, M. (2017). Belajar Dan Pembelajaran. FITRAH:Jurnal Kajian Ilmu-Ilmu Keislaman, 3(2), 333. https://doi.org/10.24952/fitrah.v3i2.945.

Permana, E. P., \& Nourmavita, D. (2017). Pengembangan Multimedia Interaktif Pada Mata Pelajaran Ipa Materi Mendeskripsikan Daur Hidup Hewan Di Lingkungan Sekitar Siswa Kelas Iv Sekolah Dasar. Jurnal PGSD, 10(2), 79-85. https://doi.org/10.33369/pgsd.10.2.79-85.

Rosmiati, M. (2019). Animasi Interaktif Sebagai Media Pembelajaran Bahasa Inggris Menggunakan Metode ADDIE. Paradigma: Jurnal Komputer Dan Informatika Univiersitas Bina Sarana Informatika, 21(2). https://doi.org/https://doi.org/10.31294/p.v21i2.6019.

Rosmiati, U., \& Lestari, P. (2021). Inovasi Model Pembelajaran PBI ( Problem Based Instruction ) Berbasis Whatsapp Sebagai Langkah Solutif Pembelajaran di Masa Pandemi Covid-19. JNPM (Jurnal $\begin{array}{llr}\text { Nasional Pendidikan } & \text { Matematika), }\end{array}$ https://doi.org/http://dx.doi.org/10.33603/jnpm.v5i1.3708 Inovasi.

Shofiyah, F. (2018). Model Problem Based Learning (PBL) dalam Melatih Scientific Reasoning Siswa. Jurnal

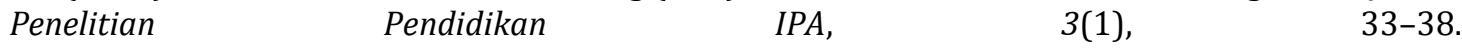
https://doi.org/http://dx.doi.org/10.26740/jppipa.v3n1.p33-38.

Siddiq, Sudarma, \& Simamora. (2020). Pengembangan Animasi Dua Dimensi Pada Pembelajaran Tematik Untuk Siswa Kelas III Sekolah Dasar. Jurnal Edutech Undiksha, 8(2), 49-63. 
https://doi.org/http://dx.doi.org/10.23887/jeu.v8i2.28928.

Silmi, M. Q., \& Rachmadyanti, P. (2018). Pengembangan Media Pembelajaran Video Animasi Berbasis Sparkol Videoscribe Tentang Persiapan Kemerdekaan RI SD Kelas V. Jurnal Penelitian Pendidikan Guru Sekolah Dasar, 6(4), 254987.

Supriyono. (2018). Pentingnya Media Pembelajaran Untuk Meningkatkan Minat Belajar Siswa SD. Edustream: Jurnal Pendidikan Dasar, 2(1), 43-48. Retrieved from https://journal.unesa.ac.id/index.php/jpd/article/view/6262.

Taiyeb, A. M., \& Nurul, M. (2015). Hasil Belajar Biologi Siswa Kelas XI IPA SMA Negeri 1 Tanete Rilau. Jurnal Bionature, 16(1), 8-16. https://doi.org/https://doi.org/10.35580/bionature.v16i1.1563.

Taqiya, Nuroso, \& Reffiane. (2019). Pengaruh Model Pembelajaran Terpadu Tipe Connected Berbantu Media Video Animasi. Mimbar PGSD Undiksha, 7(3), 289-295. https://doi.org/http://dx.doi.org/10.23887/jjpgsd.v7i3.19492.

Trianawati. (2019). Pengaruh Model Discovery Learning Berbantuan Media Animasi Terhadap Kompetensi Pengetahuan IPA Siswa Kelas IV SDN Gugus VI Abiansemal Tahun Ajaran 2018/2019. $\begin{array}{llll}\text { International Journal of Elementary } & \end{array}$ https://doi.org/http://dx.doi.org/10.23887/ijee.v4i1.24337.

Twiningsih, A., \& Sayekti, T. (2020). Peningkatan Keterampilan Berhitung Siswa Melalui Media Kotak Ajaib Berbasis Stem Pada Materi Konsep Penjumlahan. Jurnal Pendidikan Dasar, 11(1). https://doi.org/doi.org/10.21009/JPD.011.02.

Widiyasanti, M., \& Ayriza, Y. (2018). Pengembangan Media Video Animasi untuk Meningkatkan Motivasi Belajar dan Karakter Tanggung Jawab Siswa Kelas V. Jurnal Pendidikan Karakter, 8(1). https://doi.org/https://doi.org/10.21831/jpk.v8i1.21489.

Wijoyo, A. (2018). Pengaruh Hasil Belajar Siswa Dengan Menggunakan Multi Media Pembelajaran Interaktif Untuk Sekolah Menengah Pertama dan Sekolah Menengah Atas. Jurnal Informatika Universitas Pamulang, 3(1), 46-55. https://doi.org/http://dx.doi.org/10.32493/informatika.v3i1.1519.

Wuryanti. (2016). Pengembangan Media Video Animasi untuk Meningkatkan Motivasi Belajar dan Karakter Kerja Keras Siswa Sekolah Dasar. Jurnal Pendidikan Karakter, 6(2). https://doi.org/.https://doi.org/ 10.21831/jpk.v6i2.12055.

Yuliani, Antara, \& Magta. (2017). Pengaruh Video Pembelajaran Terhadap Kemampuan Berhitung Permulaan Anak Kelompok B Di Taman Kanak-Kanak. Jurnal Pendidikan Anak Usia Undiksha, 5(1), 96-106. https://doi.org/http://dx.doi.org/10.23887/paud.v5i1.11309. 